\title{
The Protagonist's Masculine Perceptions in Things Fall Apart as the Sign of Igbo Society Breakup
}

\author{
Jean Damascene Ngendahayo, (MA Ed \& MTh) \\ Faculty of Education, Ruhengeri Institute of Higher Education, Rwanda
}

\begin{abstract}
Things Fall Apart (TFA) is the novel written and published by Chinua Achebe in 1958 for recounting all social and cultural life and beliefs as well as the arrival of British Colonizers in the Igbo society of Nigeria. This paper aims at identifying the effects of the protagonist's masculine perception in Things Fall Apart as the sign of Igbo society breakup. Okonkwo, the protagonist of the TFA is said in the whole novel and his different behaviors are still analyzed until now. This study elucidates the Okonkwo's resistance against the British colonizers where he refuses to submit himself to them after slaying their messenger and prefers to die as a man by hanging himself, the act the Igbo society consider like an abomination. Along with that, the research analyzes how much Okonkwo scorns the women by considering them like weak people. Based on the analytical findings, this research reveals how his masculine perceptions portray the breakup of Igbo society socially and culturally as it has been noticed from TFA where he often blames those who behave like a woman among his clan members. The protagonist's suicide openly exhibits the end of traditional Igbo society for the benefit of the British colonizers.
\end{abstract}

Keywords: Masculine, perception, Protagonist, Gender Abuse, Society breakup

DOI: $10.7176 / J L L L / 75-02$

Publication date: January $31^{\text {st }} 2021$

\section{INTRODUCTION}

The village of Umuofia is the symbolic heart of Things Fall Apart, as well as the setting for much of the novel's action. Umuofia, where the protagonist, Okonkwo, lives for most of the novel, serves to represent Nigerian village society, both before and after contact with the colonizing forces of the British Empire. Okonkwo's world is also shaped by a social hierarchy, which sheds light on the values of his people. Achebe notes, "Age was respected among his people, but achievement was revered" (8). And it is through the strength of his own achievements that Okonkwo gains his prominent social position. Originally gaining fame through his wrestling prowess, he proceeds to distinguish himself in a war, become a successful farmer, and gain some of the overt signs of social position: wives and titles. Okonkwo's history shows that the Ibo value strength, bravery and success. As the real protagonist of TFA, Okonkwo also strives to make his way in a culture that traditionally values manliness. Men in different countries of Africa are considered like superpowers and leaders of their societies where women have no rights to object to that mindset that minimize their values. In Africa, if a person does an action which is not good or takes a decision which is unlike to masculine ones, they tell him or her that he/she has taken a womanish decision. Though, in the first book of the Holy Bible, Genesis 1, God stated that men and women were equally created in the image of God and neither attained more of the image of Him than the other. This concept which was introduced based on religious views was then wronged in time when people began to react in a stereotypical manner towards women. People started having views on women which placed them at a much lower level than men.

Our lives are influenced by our peers and there believes. For instances, Ibo tribes in Africa believe in male masculinity and dominance, such that all individuals are conditioned from a young age to understand the concept of male superiority. Anyone who strays away from this believe is shunned by the community or considered weak. In Chinua Achebe's Things Fall Apart the main character Okonkwo's life is based upon the belief of male masculinity and hard work. He prides himself on his masculinity and does not accept failure or weakness of any kind including any from his family members. In Things Fall Apart, Achebe depicts negative as well as positive elements of Igbo culture, and he is sometimes as critical of his own people as he is of the colonizers. Many cases of women oppression such as inequality, Women beating, lack of inheritance for female children and abusing femininity were hereby regarded as the big problem between Igbo men and women to the societal unity and equality.

The present paper aims at identifying how the masculine perceptions of the protagonist of Things Fall Apart which lead to the breakup of the Igbo society. Okonkwo was once considered the greatest warrior alive, but he cannot stop the European Christian white men who have come in to take control and change his village traditions. Okonkwo finally gives up hope and hangs himself, even though it is a disgrace to commit suicide in his tribe. His suicide is a horrifying act that strips him of all honor and denies him the right to an honorable burial though Okonkwo thinks that committing suicide is good enough to show his tribe and the British colonizers his masculine insight. So, the present study has to shed light on the effects of the protagonist's masculine perception towards his Igbo society. 


\section{RESEARCH METHOD}

In order to address this problem of masculine perception of Okwonko regarded as the sign of his Igbo society destruction, the research uses the analytical approach which is based on literary criticism upon the masculine perception of the main protagonist, Okwonko, of the Things Fall Apart by Chinua Achebe. The indicators of personality of the protagonist are focused on so that the research can prove whether the masculine perception of Okwonko has led the Igbo society to its breakup. This study uses the novel of Chinua Achebe whose title is "Things Fall Apart" published for the first time in 1958. In fact, analytical analysis is used for helping the reader of this research to easily discover all the Okwonko's masculine deeds which have been predicted as the root causes of his Igbo society breakup. In addition to this novel of Achebe, the researcher tries to read and analyze other related researches that can shade the light on the problem of masculine perception or traits of the protagonist of TFA which are said to make his society fall apart. This research is only dealing with qualitative due to the fact it has identify all masculine perception or stereotypes which are taken as the sign of the Igbo society breakup. The logical reasoning has been used to connect both variables of this study. The research has briefly identified what caused Okonkwo to be characterized by hyper-masculine and traumatized by the failure of his father Unoka, who did not achieve any titles during his lifetime and was heavily in debt at the time of his demise (Achebe 7). Apart from that, this approach has to collect all information from chapters that depict the Okonkwo's masculine perception as the sign of his Igbo society destruction. Okonkwo, who is a traditional and proud Igbo man, has an antipathy toward what is considered to be weak and feminine. Okonkwo is therefore struck with depression when he finds himself in a weak and helpless position, as well as emasculated emotional state of mind.Without any reservation whatsoever, Okonkwo decided to become the opposite of his father Unoka whom he considers weak and effeminate.

\section{THE ANALYSIS AND DISCUSSION OF THE MASCULINE PERCEPTION OF OKONKWO}

The novel follows the life of Okonkwo, an Igbo ("Ibo" in the novel) man and local wrestling champion in the fictional Nigerian clan of Umuofia. The work is split into three parts, with the first describing his family, personal history, and the customs and society of the Igbo, and the second and third sections introducing the influence of European colonialism and Christian missionaries on Okonkwo, his family, and the wider Igbo community. The study was written for the purpose of shedding the light on the issue of masculine perception of the protagonist in Chinua Achebe's TFA where this stereotype of Okonkwo is thought to be the destruction of his Igbo society during colonial period. The society embodies different things such as beliefs and culture etc. So, culture and beliefs of Igbo people have considerably fragmented when trying to read this novel thoroughly.

In the final chapters of Achebe's novel TFA where he returns from the exile of seven years at Okonkwo's mother's native village known as Mbata, Okonkwo finds his village changed by the presence of the white men. After a convert commits a heinous act by unmasking an elder as he embodies an ancestral spirit of the clan, the village retaliates by destroying a local Christian church. After doing that action against white colonizers, the District Commissioner who represents the colonial government takes Okonkwo and other native leaders for jailing them and pay a fine of two hundred cowries. Despite the District Commissioner's instructions to treat the leaders of Umuofia with respect, the native "court messengers" humiliate them, doing things such as shaving their heads and whipping them. As a result, the people of Umuofia finally gather for what could be a great uprising. Okonkwo, a warrior by nature and adamant about following Umuofian custom and tradition, despises any form of cowardice and advocates war against the white men. When messengers of the white government try to stop the meeting, Okonkwo beheads one of them. Because the crowd allows the other messengers to escape and does not fight alongside Okonkwo, he realizes with despair that the people of Umuofia are not going to fight to protect themselves - his society's response to such a conflict, which for so long had been predictable and dictated by tradition, is changing.

In one section of the book which is suggestively entitled "Fragmenting Culture Fragmenting Lives," the writers tackle the issue of gender in this novel. They say that "one of the norms of Igbo culture is the sharp division between what is feminine and what is masculine. From simple farm crops to complex human actions and emotions, Things Fall Apart portrays a culture where real and symbolic gender distinctions abound" (283). So, the Igbo society differentiates between feminine and masculine in all the aspects of life, including the crops. In other words, all what shows strength is related to men and all what shows weakness is related to women. Women, according to the Igbo society, represent the weakness in the culture of their society. Women in Things Fall Apart are in general thought of as the weaker sex. At a first glance, women are the laborers, and the producers of children. They are not respected as real people, but are more just the men's property. All they have to do is to be good housewives, and make sure to please their husband at all times. For this reason, women have no identity of their own; but are defined by the status or position of their husband.

\subsection{Literary picture of Igbo society before and after the arrival of British colonizers}

In sociological terms, society refers to a group of people who live in a definable territory and share the same culture. 
On a broader scale, society consists of the people and institutions around us, our shared beliefs, and our cultural ideas. The term society as mentioned earlier is derived from a Latin word socius. The term directly means association, togetherness, gregariousness, or simply group life. The concept of society refers to a relatively large grouping or collectivity of people who share more or less common and distinct culture, occupying a certain geographical locality, with the feeling of identity or belongingness, having all the necessary social arrangements or insinuations to sustain itself. We may add a more revealing definition of society as defined by Calhoun et al (1994): "A society is an autonomous grouping of people who inhabit a common territory, have a common culture (shared set of values, beliefs, customs and so forth) and are linked to one another through routinized social interactions and interdependent statuses and roles." Society also may mean a certain population group, a community Introduction to Sociology 63 The common tendency in sociology has been to conceptualize society as a system, focusing on the bounded and integrated nature of society.

During the Week of Peace, Okonkwo notices that his youngest wife, Ojiugo, has left her hut to have her hair braided without having cooked dinner. He beats her for her negligence, shamefully breaking the peace of the sacred week in a transgression known as nso-ani. The priest demands that Okonkwo sacrifice a nanny goat and a hen and pay a fine of one length of cloth and one hundred cowries (shells used as currency). Okonkwo truly repents for his sin and follows the priest's orders. Ogbuefi Ezeudu observes that the punishment for breaking the Peace of Ani has become mild in Umuofia.

With the above explanation and even Achebe's writings illustrate how Okonkwo, though a hero of his clan, did not care about the norms of his society. It is also clear that the protagonist was not afraid of anything. He beats his wife Ojiugo when it was not permissible for her to speak ill or quarrel with him because it could anger the god of earth. He was not advised and accepted anybody's advice. Masculine behavior which pushed him to make difference form his late father who left nothing to his son Okonkwo. As a result, his family, friends and the entire clan left him alone. And this also shows how the masculine nature made Okonkwo end up committing suicide and their culture fragmented all the people scattered and split into many white followers who abandoned their traditional traditions for Christianity.

Christianity was first introduced to the Igbo people through European colonization in 1857 . The Igbo people were hesitant to convert to Christianity initially because they believed the gods of their native religion would bring disaster to them. However, Christianity gradually gained converts in Igbo land, mainly through the work of church agents. These men built schools and focused on persuading the youth to adopt Christian values. The Igbo people today are known as the ethnic group that has adopted Christianity the most in all of Africa. The Igbo people today are known as the ethnic group that has adopted Christianity the most in all of Africa. The Igbo people were unaffected by the Islamic jihad waged in Nigeria in the 19th century, but a small minority converted to Islam in the 20th century according to (Okeke, Chukwuma O., 2017)

In view of Things Fall Apart, it is set in the 1890s and portrays the clash between Nigeria's white colonial government and the traditional culture of the indigenous Igbo people. Achebe's novel shatters the stereotypical European portraits of native Africans. He is careful to portray the complex, advanced social institutions and artistic traditions of Igbo culture prior to its contact with Europeans. Yet he is just as careful not to stereotype the Europeans; he offers varying depictions of the white man, such as the mostly benevolent Mr. Brown, the zealous Reverend Smith, and the ruthlessly calculating District Commissioner. Achebe shows that the Ibo nonetheless assign important roles to women. For instance, women painted the houses of the egwugwu (Achebe, TFA 84). Women in Things Fall Apart are the primary educators of children. Through storytelling and behavior, they educate and socialize the children, inspiring in them curiosity about social values, relationships, and the human condition. The stories the women tell also develop the artistic consciousness of the children, in addition to entertaining them. Furthermore, the first wife of a man in the Ibo society is paid some respect. This deference is illustrated by the palm wine ceremony at Nwakibie's obi. Anasi, Nwakibie's first wife, had not yet arrived and "the others [other wives] could not drink before her" (Achebe, p.22).

\subsection{The masculine lifestyle for the protagonist in Things Fall Apart}

According to Chimdi Maduagwu (2011), the society on which the story of Achebe's Things Fall Apart is based, the fictional Umuofia, can be any society in Igboland, in the present southeastern Nigeria. Its uniqueness is reinforced by the strong cultural notion of "otherness." In other words, the males are different from the females, on one hand; and on the other, some males who have distinct male characteristics (masculine) are different from other men. The obvious considerations of the term, masculinity thus draw upon the perceived differences between the male and female sexes, and equally within the (male) sex. In other words, at the ordinary level, the masculine character is likely to be a man, different from the woman. However, this is not enough, because, the man in question should be distinct in order to be properly masculine

Okonkwo dedicates himself to being as masculine as possible, and through his rise to become a powerful man of his tribe and subsequent fall both within the tribe and in the eyes of his son Nwoye, the novel explores the idea of masculinity. Okonkwo believes in traditional gender roles, and it pains him that his son Nwoye is not more 
aggressive like he is. As a result, it's revealing that he expresses the wish that his daughter Ezinma were a boyfrom this we know how fond he is of her. Additionally, in a meeting towards the very beginning of the book, Okonkwo insults a man without title by calling him a woman, demonstrating how much masculinity is valued when ranking those in Umuofia society. Ultimately, though, Okonkwo's adherence to masculinity and aggression leads to his fall in society - he becomes brittle and unable to bend with the changes taking place in his clan. In keeping with this principle of masculinity, Okonkwo forces himself to kill his own surrogate son, murder the white man against his better judgment, and hang himself before a punishment can be imposed by others. Okonkwo's aggression makes him weak in the end - it leaves him with no room to maneuver against the more subtle ways of the white man.

All aspects of Okonkwo's life were devoted to masculinity. Even when farming he was conditioned by his clansmen that yams their staple crop is the king of crops. This is further the male dominance in the Ibo culture because males will be the only people able to provide for the family. When his family was working hard to provide food he thought it would not help because they could not grow yams. He thought that" His mother and sisters worked hard enough, but they grew women's crops, like coco-yams, beans and cassava."(pg.19) and that "Yam, the king of crops, was a man's crop" (pg. 19). These beliefs caused him to seek yams seeds at a young age to try to help grow crops for his family.

Throughout the novel Okonkwo does not show any signs of compassion for his children. In his perspective it is effeminate and a sign of weakness. This is also the reason why he never shows any love for his daughter Ezinma. He even stated "that he will not have a son who cannot hold up his head in the gathering of the clan" (pg. 28) and that he would rather "strangle him with his own hands." (pg.28). At one point he scolded Nyowe his eldest son and Ikemefuna his adoptive son about how to grow yams properly. "Inwardly Okonkwo knew that the boys were still too young to understand fully the difficult art of preparing seed-yams. But he thought that one could not begin too early. Yam stood for manliness, and he who could feed his family on yams from one gravest to another was a very great man indeed" (pg. 28). This shows how important being a man is and how being effeminate will not be tolerated in his household while he is alive. In $T F A$ the number of wives you have affects social status. Okonkwo wishes that his favorite child, Ezinma, should have been a boy. In Igbo society women were looked as nothing and only blessed with rearing children and that their lives should be confined to the domestic sphere. The protagonist of Things Fall Apart, Okonkwo was a man who demonstrated the power and heroism in his life whereby he feared to be called weak or a woman. Okonkwo is evidently torn between his manly aspirations, the fear of being emasculated, and the guilt for killing his adopted son. This emotional contradictory state becomes, for example, evident in this following passage: "'When did you become a shivering old woman,' Okonkwo asked himself, 'you are known in all the nine villages for your valour in war. How can a man who has killed five men in battle fall to pieces because he has added a boy to their number? Okonkwo, you have become a woman indeed" (Achebe 60$61)$

\subsection{Male dominance and its impact on the society}

When the European colonizers arrive in Nigeria, they change many things related to the society and culture. Henceforth, women start losing their value in the society whereby men dominance obviously takes place against women. According to the British colonizers in Nigeria, the society has to be more patriarchal than matriarchal. This means that women are deprived from parents' inheritance and they should do everything regarding the men's needs. The boy child is allowed to be given his father inheritance but for a girl, it is prohibited. Though the protagonist of Things Fall Apart known as Okonkwo; his quick temper with his family is never portrayed as admirable, he unquestionably has the right to be aggressive at home. Oftentimes women and female children are synonymous with the kitchen. Some of these women are voiceless no matter the treatment meted to them.

The beliefs of Okonkwo on the handling and treatment of issues termed feminine are not a cultural belief, but personal as other successful and prosperous men are observed not to share in his handling of some societal issues. The beating of women, the involvement in the killing of Ikemefuna, the agitation to wage war against the white missionary in both Umuofia and Mbanta were some of the issues where Okonkwo did not have full support from other men in the society, and his reason for terming them „effeminate ${ }^{\text {ee }}$ It's stressed that a man is the head of the family and his wives do his bidding" (TFA, p.132). Here, Uchendu describes the male dominance and female suppression in Chinua Achebe's book Things Fall Apart. Uchendu exemplifies one of the few male characters who understood and displayed gratefulness for the important role women played in his Igbo society. In this Igbo culture based on male prosperity - men were higher up on the social scale and earned more respect and honor if they possessed more riches, titles and wives. Women are regarded as unnecessary except for rearing children and performing tasks such as the equivalent of domestic chores.

\subsection{The particular behaviors of masculinity of Okonkwo}

With the view of Elisabeth Horan (2014), we can review the masculine/feminine binary to show that the masculine gender typically holds the power in Igbo society while feminine gender represents the weak. Okonkwo reacts with 
violence and severe disapproval if provoked by any femininity shown by his sons by chastising them and beating them. This correlates with the way the natives are treated by the colonizers but in a reverse gender dynamic: the colonizers react with violence if the natives show any masculine tendencies - if they fight back, if they resist, or if they taunt the white colonizers: "The court messengers did not like to be called Ashy-Buttocks, and they beat the men. But the song spread in Umuofia" (Achebe, 1902). The colonized people are praisedfor feminine traits such as acting submissive and not questioning the power of the church or the new nation.

By Joakim Pars (2019), both Ikemefuna and Nwoye were friends even if the first one consider and call Okonkwo, father. Okonkwo did not like to see the close friendship and unity of those two young boys. They are forced to feign masculine characteristics to appease their angry father. So, Okonkwo himself encourages Ikemefuna and Nwoye to "grumble about women and their troubles" (Achebe, 578), initiating within them a disrespect for the women in their world who have loved and cared for them. This is Okonkwo's tactic of colonizing his boys to be masculine - he uses fear and violence to suppress their naturally feminine characteristics while at the same time sparking the idea of considering the women in their lives to be less than worthy of their attention and respect. Different horrible things, Okonkwo did like breaking the peace of the sacred week and killing Ikemefuna irreparably created a great shock to his clan people and the gods of earth. He used to severely beat his wife and caution his daughter by saying that he wishes Ezimna had been born a boy. To mean that being a woman was abominable to his characteristics of masculinity. After killing his adopted son Ikemefuna, Okonkwo did not have any peace in his mind though he considered this killing like a manly act. This leads Okonkwo's son, Nwoye, to fear and run away from him because he has just known his father has shed the blood of innocent boy, Ikemefuna. In short, Okonkwo genuinely fears becoming like his father. He genuinely feels that his father was too feminine, and Okonkwo tries to compensate by being hyper-masculine. (Jonathan B., 2014). When the Christian missionaries arrive and try to change the customs of Umuofia. Okonkwo is saddened and enraged by the new religion and government, but most of all by how his own clansmen abandon their old ways: "What is it that has happened to our people? Why have they lost the power to fight? .. . We must fight these men and drive them from the land" (124). It is clear that his clansmen have just gone to the side of the white people there in Umuofia and they had no will to fight them as Okonkwo did but in vain.

\section{CONCLUSION}

Having read the Chinua Achebe's Things Fall Apart (TFA), it shows how Okonkwo struggles to make difference from his Father, Unoka who was lazy, unable to support his family, and cowardly. Okonkwo as protagonist in TFA considers Okonkwo considers many of his father's characteristics to be feminine. These behaviors and mindsets of Okonkwo pushed him to be brutal every time to everybody who tries to show the feminine behavior including his wives and children. As it was critically analyzed from the above chapters, it has shown that the protagonist's personality frequently brought his him into conflicts with others. The typical example was his extreme commitment to masculinity which comes to a head when he takes responsibility for executing his own adopted son, Ikemefuna despite the refusal of the Ogbuefi Ezeudu's warning against that unjustified killing of his adopted son. For Okonkwo this act was masculine. His brutal behaviors were identified in the whole novel and this leads him into exile for seven years in Mbanta. When he was in exile, everybody and everything in Umuofia changed where colonisers kept converting the Igbo people for their Christianity including Okonkwo's old son, Nwoye. When Okonkwo returns from the exile, he tries to remain strong against the tide of change, but he seems to stay alone without anyone to support him in his masculine fights against the British settlers. As he disowns his father Unoka, his tribe also disowns him by submitting to British colonizers. The Okonkwo's struggle of showing his masculine perception and power differently from effeminate people pushes him to cut off the white messenger's head without consulting those who are together with him in the meeting. Even though, some people can say that Okonkwo was a hard worker man from the beginning to the end of TFA, it cannot prevent anyone from saying that he was a murderer where he used a machete and gun to do what he himself called manliness. This last event of killing the British messenger leads the life of Okonkwo to the death of hanging himself because he had no choice and the drive to submit himself to the new colonial government in his area. Socially and culturally, the Igbo society which is strong and united got broken down because of the fear of being called weak or a woman even though his death by suicide depicts the effeminate of Okonkwo at the end. It also displays how taboo of suicide was applied by the hero man like Okonkwo. The remarkable lesson for all the readers including Nigerians is that, the worry of being weak or effeminate for Okonkwo has messed up the cultural and social living of Igbo people in general because for him to adhere to the British colonizers is a sign of weakness though by what Okonkwo was known as masculine ended as feminine character when he preferred not to die in the hands of the colonizers through making a cultural taboo of hanging himself on the tree. From that the culture got fragmented, the Igbo people also disowned their tradition and religion for the benefit and success of the British culture and religion. The protagonist's death strongly depicted the end of traditional culture and beliefs of the Igbo society based on the above critical analysis and interpretation of the TFA protagonist' perceptions and attitudes against all looked considered effeminate character from anybody in his Igbo society. 


\section{Conflicts of Interest}

The authors have declared no conflicts of interest. I also agree that I will not use any confidential information obtained from my activities with JLLL-Journal of Literature, Languages and Linguistics to further my own or others financial interests.

\section{Author's Profile}

Jean Damascene Ngendahayo was born in Rwanda. He is currently a Language Center Coordinator and Assistant Lecturer in the faculty of Education at Institut D'Enseignement Supérieur de Ruhengeri (INES-Ruhengeri) in Rwanda since February 2019. Prior to his recent appointment at the above mentioned institution, he was a parttime lecturer at Christian University of Rwanda at Kigali and Kibogora Polytechnic located in the Western of Rwanda from 2017 to 2019 . He also combined this visiting with his permanent teaching in public secondary schools in Rwanda. He received his Master's degree of Arts in English Language and Literature Education (MA ED) from Kampala University, Uganda in March 2016 and also obtained a Master of Theology (MTh) by International Christian University (ICU), USA in January 2019 where he got an excellent grade and was therefore awarded the doctorate scholarship by ICU founder and he is now pursuing his Theology Doctorate (DTh) in the same university. He published some papers in preferred Journals and participated in some academic discussions and conferences. His areas of interests include education, linguistics, English language and literature as well as Theology. He has 3 years of research and teaching experience of more than 10 years in the areas of English language, Literature, communication skills in English and French as well as Kiswahili language.

\section{References}

1. Achebe, C. (1958). Things Fall Apart. Essex: Heinemann, Print.

2. Achebe, C. (1958). Things Fall Apart. New York: Random House, Inc. New York

3. Calhoun, Craig, et al. 1994. Sociology. 6th Ed. New York: McGraw Hill. https://www.cartercenter.org/resources/pdfs/health/ephti/library/lecture notes/health science students/ln s ociology final.pdf

4. Chimdi Maduagwu (December 2011), Masculinities in Achebe's TFA. International Journal of Humanities and Social Science Vol. 1 No. 20, University of Lagos, Nigeria

5. Elinor Lowery, (July 2007) In Things Fall Apart, why does Okonkwo commit suicide and what is the final message of this work?

6. Elisabeth Horan (2014), Okonkwo Between Two Worlds: Investigation of Masculine/Feminine Binaries in Things Fall Apart by Chinua Achebe

7. Greenaway, Theresa; Rolf E. Johnson; Nathan E. Kraucunas (2002). Rain Forests of the World. Marshall Cavendish. p. 292. ISBN 978-0-7614-7254-4.

8. Hoffman, R. M., Borders, L. D., \& Hattie, J. A. (2000). Conceptualizing femininity and masculinity: From gender roles to gender self-confidence. Journal of Social Behavior and Personality, 15, 475-503

9. Hoffman, R.M., Hattie. J. A. \& Borders, D. L. (2005). Personal Definitions of Masculinity and Femininity as an Aspect of Gender Self-Concept. Journal of Humanistic Counseling, Education and Development. 44.

10. Justin Cowlin (2011) Why do Things Fall Apart? A Psychological Analysis of Okonkwo's Personality and his Ultimate Demise in Chinua Achebe's Novel Things Fall Apart. https://www.divaportal.org/smash/get/diva2:403307/fulltext01.pdf

11. Okeke, Chukwuma O.; Ibenwa, Christopher N.; Okeke, Gloria Tochukwu (2017-04-01). "Conflicts Between African Traditional Religion and Christianity in Eastern Nigeria: The Igbo Example". SAGE Open. 7 (2): 2158244017709322.

doi:10.1177/2158244017709322. ISSN 2158-2440

12. Salaam, T. (2003) A Brief Analysis On The Situation Of Women In Nigeria Today, DSM. Women's Studies: Feminist Theory and Practice. Macmillan, London.

13. Smuthkochorn, Sutassi (2013). "Things Fall Apart". Journal of the Humanities. 31: 1-2.

14. Stacey, J. (1993) "Untangling Feminist theory" in Richardson D. and Robinson V. (eds.) Introducing women's Studies: Feminist Theory and Practice. Macmillan, London. The Constitution of the Federal Republic of Nigeria

15. Tobalase Adegbite O. (June 2016) Masculinity and cultural conflict in Chinua Achebe's Things Fall Apart, rticle Number - 510665358705, Vol.7(6), pp. 81-87, https://doi.org/10.5897/IJEL2015.0764

16. UKEssays. (November 2018). Things Fall Apart Masculinity English Literature Essay. Re trieved from https://www.ukessays.com/essays/english-literature/things-fall-apart-masculinity. Retrieved 15:36, November, 2020

17. Joakim Pårs, (2019) A Feminist and Postcolonial Literary Analysis of the Concept of Emasculation in Things Fall Apart. University Gavle. 